\title{
Academic, Out-of-Classroom Experiences and Overall Adjustment of Freshman Students at a Midwestern University
}

Beth M. Lingren and Marybelle C. Keim

Researchers investigating academic experiences of freshman college students include Blinne and Johnston (1998), Hickman, Bartholomae, and McKenry (2000), Jaasma and Koper (1999), Pascarella and Terenzini (1977), Tinto (1997), and Woodside, Wong, and Weist (1999). Blinne and Johnston were concerned with students' vocational identity and persistence in college, while Hickman et al. examined the relationship between parenting styles, academic achievement, and adjustment of students. Pascarella and Terenzini, as well as Jaasma and Koper, investigated relationships between students and faculty outside the classroom. Tinto reported on a study that involved participation in a shared classroom learning experience. Woodside et al. hypothesized that positive student-faculty interactions would result in higher levels of academic achievement among students.

Berger (1997), Fidler (1991), Pascarella, Terenzini, and Wolfle (1986), and Pike, Schroeder, and Berry (1997) examined out-of-classroom experiences. Berger investigated how a sense of community on each floor of a freshman residence hall affected social integration, while Fidler and Pascarella et al. researched the influence of orientation programs on persistence and withdrawal decisions. Pike et al. examined the relationship between effects of residential and nonresidential communities on student interactions and persistence.

Overall adjustment to college was studied by Baker and Siryk (1986), Gerdes and Mallinckrodt (1994), Jackson (1998), and Martin and Dixon (1994). Baker and Siryk as well as Gerdes and Mallinckrodt attempted to identify students at risk for dropping out because of poor overall adjustment to college, and suggested areas for proactive interventions. Martin and Dixon analyzed the impact of freshman orientation attendance and locus of control as it related to college students' adjustment to college. Jackson conducted research to determine factors related to freshman adjustment to college.

\section{Theoretical Framework}

The theoretical framework guiding the current research was Tinto's (1987) Model of Student Departure. Tinto theorized that a student attends college with a variety of characteristics including family background, personality, and academic characteristics. Student expectations, personal goals, and intentions involving the college experience 
vary. These characteristics, goals, and expectations are altered and reformulated as students interact with individuals and structures, both academic and social in nature, within the college environment. Positive, rewarding interactions within the college environment contribute to student retention. The higher the levels of academic and social integration, the less likely the student is to leave the institution voluntarily (Tinto, 1975, 1987).

According to Tinto (1987), in order to retain students, institutions must be able to assist them with their integration into academic and social communities. Being proactive with student transitions can lessen or eliminate situations dealing with adjustment, incongruence, and isolation during the college experience.

\section{Purposes of the Study}

The purposes of the study were to assess (a) academic experiences, (b) out-ofclassroom experiences, and (c) overall adjustment of freshman students at a Midwestern, public, four-year university. A fourth purpose was to compare the findings with students' experiences at five peer institutions.

\section{Methods}

At a large, comprehensive public university in the Midwest (called "Midwestern University" for the purposes of this study), more than 1,000 freshmen were selected using cluster sampling to participate in this study. Students enrolled in 89 sections of English 102 were administered the "Your First College Year" (YFCY) instrument (Higher Educational Research Institute, 2001) in regularly scheduled classes during spring 2002. YFCY identifies institutional features of the freshman year that encourage student involvement, satisfaction, and success.

YFCY is a national survey designed by researchers at the University of California at Los Angeles and sponsored by a grant from the Pew Charitable Trusts. The instrument was tested for reliability and validity during a pilot phase involving students in 19 two- and four-year institutions, and was deemed valid and reliable (Sax, 2000). The 23-question instrument (1) addresses students' academic experiences, (2) measures retention, (3) evaluates student adjustment to college, (4) assesses first-year programming, and (5) investigates students' personal experiences during the first year.

Because of the extensive amount of data generated by the YFCY (198 specific variables), a peer panel, comprised of 15 student affairs professionals whose primary responsibilities involved working with first year students, determined the most salient variables for analysis in this study. At a National Orientation Directors Association annual conference, panelists were instructed to rank the five most important items within the categories of academic experiences, first-year experiences (renamed out-of-classroom experiences), and overall adjustment to college. The top ranked questions became the focus of this study.

The academic items selected were (a) understanding what professors expect of 
students academically, (b) getting to know faculty, (c) adjusting to the academic demands of college, and (d) developing effective study skills. The out-of-classroom experience variables were (a) developing close friendships with other students, (b) having a sense of community among students, (c) taking a college course or seminar specifically designed to assist first-year students in adjusting to college (e.g., freshman seminar, University 101), (d) enrolling in a formal program in which a group of students takes two or more courses together (e.g., freshman interest group, learning cluster, learning community), and (e) participating in student clubs or groups. The overall adjustment questions were (a) managing time effectively and (b) developing a meaningful philosophy of life.

\section{Findings}

Of the 833 instruments submitted for processing, 784 were usable; all participants were first-year, full-time freshmen. The gender representation was 51\% male and $49 \%$ female. Race included $72 \%$ Caucasian, $16 \%$ African-American, and $12 \%$ other or unidentified. The percentages varied slightly from the actual demographics at the institution, which were reported as 56\% male, $44 \%$ female, $72 \%$ Caucasian, $9 \%$ African-American and 18\% other (National Center for Educational Statistics, 2001).

Findings were compared with data from peer institution students $(n=2,734)$ who also had completed the YFCY. The comparable institutions, which also had similar undergraduate enrollments of approximately 17,000 students, were North Carolina State University, Northern Illinois University, Texas A \& M University, University of Missouri-Columbia, and West Virginia University.

\section{Academic Experiences}

Response levels for academic experiences were as follows: $4=$ completely successful, $3=$ fairly successful, $2=$ somewhat successful, and $1=$ unsuccessful. Overall means were calculated for the total group of Midwestern University and peer institution students. Students perceived that they were fairly successful in understanding what professors expected academically $(M=3.01)$ and adjusting to academic demands $(M=2.99)$. They ranked developing effective study habits $(M=2.67)$ between fairly successful and somewhat successful and getting to know faculty $(M=2.25)$ as somewhat successful.

Analysis of variance statistical techniques revealed several statistically significant differences between Midwestern and peer institution students. First, Midwestern students showed greater success in getting to know faculty than at peer institutions $(p<.002)$. Second, Midwestern students showed greater success adjusting to academic demands of college life than at peer institutions ( $p<.0001)$. Third, Midwestern students, both male and female, showed greater success adjusting to the academic demands of college than students at peer institutions $(p<.008)$. Fourth, female students showed greater success developing effective study skills than male students $(p<.024)$. Finally, Midwestern students in all race categories showed greater success adjusting to the academic demands 
of college than students at peer institutions $(p<.021)$.

\section{Out-of-Classroom Experiences}

Means were calculated for all students for out-of-classroom experiences. Response levels were as follows: $4=$ very satisfied, $3=$ satisfied, $2=$ neutral, and $1=$ dissatisfied. Students were satisfied with developing close friendships with other students $(M=3.30)$ and having a sense of community among students $(M=2.84)$. Participating in student clubs/groups $(M=2.38)$ was ranked between the neutral and satisfied categories. Twenty-eight percent of students took a college course specifically designed to assist first-year students in adjusting to college and $16 \%$ enrolled in a formal program where a group of students took two or more courses together (i.e., learning clusters/learning communities).

Statistically significant differences between Midwestern University and peer institution students in out-of-classroom experiences were found in several areas. Peer institution students showed greater satisfaction having an overall sense of community than Midwestern students $(p<.0001)$. Peer institutions also enrolled more students in learning cluster/learning community courses than did Midwestern University $(p<.0001)$. Peer institution students participated at a higher level in student clubs and groups than did Midwestern students $(p<.001)$. Peer institution students in all race categories showed a higher degree of satisfaction with the overall sense of community among students on their campuses than Midwestern students did ( $p<.003)$. Also, more Caucasian peer students took a first-year adjustment course than Midwestern Caucasian students $(p<.002)$.

\section{Overall Adjustment}

In this category, means were also determined for all students. Response levels were as follows: $4=$ essential, $3=$ very important, $2=$ somewhat important, and $1=$ not important. The overall mean for managing time effectively was 2.61 and for developing a meaningful philosophy of life, the mean was 2.49 ; both categories were rated between somewhat important and very important.

Statistically significant differences between Midwestern and peer institution students were that Midwestern female and male students showed greater success in managing time effectively than did peer institution students $(p<.003)$, and females at peer institutions and males at the Midwestern institution showed greater success developing a meaningful philosophy of life than Midwestern females and peer males did $(p<.0001)$; (3) Caucasian and African-American peer institution students and Midwestern "other" students showed greater success in developing a meaningful philosophy of life than their counterparts $(p<.0001)$. 


\section{Disc ussion}

Even though several variables examined in this study showed statistical significance, student responses were in the middle to low ranges of the response scales regarding success, satisfaction, and importance. The highest means were understanding what professors expect academically, adjusting to academic demands, developing close friendships with other students, and having a sense of community among students. Among the lowest means were getting to know faculty and participating in student clubs or groups.

It appears that both the Midwestern and peer institution students understood their academic commitments, although students were not acquainted with faculty members to a great extent. Midwestern students' perceptions of getting to know faculty showed a higher level of success than did those of students at peer institutions. This finding may have been the result of small English classes (20 or fewer students) that participants in the study were enrolled in, with many sections being taught by teaching assistants. Other freshman students enrolled in classes with large numbers of students may have had quite different perceptions.

Graduation rates at the universities in the study, which might be interpreted as retention rates, vary considerably, from 39\% to $75 \%$ (Chronicle of Higher Education Almanac, 2004-5). Perhaps faculty at universities at the lower end of the scale should attempt to become more student friendly or at least make an effort to foster effective student-faculty relationships. It may be that faculty at universities with lower graduation rates are not rewarded for involvement with students outside the classroom. Without equivocation, faculty should be reminded of the need to list office hours on course syllabi, and to be available during office hours and before and after classes. Astin (1975), Boyer (1987), and Pascarella and Terenzini (1977) emphasized positive faculty-student interaction as being of critical importance for student success and persistence in college.

Peer institution students were more satisfied with out-of-class experiences than Midwestern students. Peer students reported a higher sense of community among students, were more likely to enroll in first-year transition courses and in learning clusters, and spent more time participating in student clubs/groups than Midwestern students did. The variables examining enrollment in a first-year course and learning clusters showed statistical significance; however, few students enrolled in these experiences.

A first-year orientation course and learning clusters are available at Midwestern University, but are not required; consequently, few students select the course as an elective or participate in the residence hall learning communities. It may be that the course and learning clusters are not supported with necessary personnel and resources, and therefore are not as effective as they are at peer universities.

According to Wilkie and Kuckuck (1989), students who enroll in first-year seminars are more likely to earn higher grades, to register for subsequent terms, and to graduate. Additionally, Crissman (2001) studied experiences of freshmen enrolled in a first-year seminar course and an English course and found that students were more satisfied with 
these courses, because they had greater support from peers and stronger relationships with faculty. Universities should investigate the possibility of requiring first-year courses to improve students' chances of succeeding academically.

Residence hall learning clusters were shown to have an indirect impact on students' persistence at the University of Missouri-Columbia by increasing faculty-student interaction (Pike et al., 1997). Mostly, clusters produced higher levels of social integration for participants, which had a positive effect on persistence. Berger (1997) also discovered positive results from participation in learning cluster programs and the impact on retention. Institutions that offer learning clusters should document their successes and challenges with these activities.

The finding that students do not participate to any great extent in student clubs or groups at Midwestern University is not surprising. It is well understood that many students have other priorities, such as work and families, which preclude their participation in traditional college student activities. Other students simply may not be interested in organized group events. Student affairs professionals need to review the variety and effectiveness of activities provided to reach as many students as possible.

Astin (1975) emphasized the importance of student participation in clubs and groups and showed that out-of-classroom activities, working on campus, and living in residence halls had positive effects on student persistence. Institutions need to continue to examine and enhance their efforts involving issues of out-of-classroom experiences in order to attempt to impact retention.

Gender and race were examined within all variables and were statistically significant in some instances. Institutions may want to give consideration to specific characteristics of their students, including personal characteristics, family background, educational experiences, and abilities. An awareness of these characteristics can assist administrators in developing and implementing retention programs and addressing student needs. This is consistent with the recommendation of Pascarella and Terenzini (1991), who encouraged institutional personnel to be aware of the changing demographics of today's college students. Ting (1998) suggested that student affairs professionals consider the diversity of variables and the convergence of race and gender in predicting success and designing programs for students.

This study showed that female students at peer institution and Midwestern males perceived that they had greater success in developing a meaningful philosophy of life than their counterparts. This finding connects with Tinto's (1987) Model of Student Departure, which states that students' expectations, personal goals, and intentions involving the college experience vary. These characteristics and aspirations are altered and reformulated as students interact with individuals and structures, both academic and social in nature, within the university environment. Each university environment impacts the manner in which students transition to college. Therefore, it is important for university personnel-including administrators, faculty, student affairs, operating staff, and others - to be cognizant of the impact that each has on students and to be supportive in any way possible to assist students in achieving success academically and socially. 


\section{References}

Astin, A. W. (1975). Preventing students from dropping out. San Francisco: Jossey-Bass.

Baker, R. W., \& Siryk, B. (1986). Exploratory intervention with a scale measuring adjustment to college. Journal of Counseling Psychology, 33(1), 31-38.

Berger, J. B. (1997). Students' sense of community in residence halls, social integration, and first-year persistence. Journal of College Student Development, 38(5), 441-454.

Blinne, W. R., \& Johnston, J. A. (1998). Assessing the relationships between vocational identify, academic achievement, and persistence in college. Journal of College Student Development, 39(6), 569-576.

Boyer, E. L. (1987). College: The undergraduate experience in America. New York: Harper and Row.

Chronicle of Higher Education Almanac 2004-2005. Washington, D.C.

Crissman, J. L. (2001). Clustered and nonclustered first-year seminars: New students' first-semester experiences. Journal of the Freshman Year Experience, 13(1), 69-88.

Fidler, P. P. (1991). Relationship of freshman orientation seminars to sophomore return rates. Journal of the Freshman Year Experience, 3(1), 7-38.

Gerdes, H., \& Mallinckrodt, B. (1994). Emotional, social, and academic adjustment of college students: A longitudinal study of retention. Journal of Counseling and Development, 72(3), 281-288.

Hickman, G. P., Bartholomae, S., \& McKenry, P. C. (2000). Influence of parenting styles on the adjustment and academic achievement of traditional college freshmen. Journal of College Student Development, 41(1), 41-54.

Higher Educational Research Institute. (2001). Your first college year. University of California at Los Angeles.

Jaasma, M. A., \& Koper, R. J. (1999). The relationship of student-faculty out-of-class communication to instructor immediacy and trust and to student motivation. Communication Education, 48(1), 41-47.

Jackson, A. L. (1998). Factors related to freshman adjustment to college (Doctoral dissertation, University of Southern Mississippi, 1998). Dissertation Abstracts International, 59(08), 2882A.

Martin, N. K., \& Dixon, P. N. (1994). The effects of freshmen orientation and locus of control on adjustment to college: A follow-up study. Social Behavior and Personality, 22(2), 201-208.

National Center for Education Statistics. (2001). Integrated post secondary data system (IPEDS): Fall 2001 enrollment survey. Washington, DC: Office of Education.

Pascarella, E. T., \& Terenzini, P. T. (1977). Patterns of student-faculty informal interaction beyond the classroom and voluntary freshman attrition. Journal of Higher Education, 48(5), 540-552.

Pascarella, E. T., \& Terenzini, P. T. (1991). How college affects students. San Francisco: Jossey-Bass. 
Pascarella, E. T., Terenzini, P. T., \& Wolfle, L. M. (1986). Orientation to college and freshman persistence/withdrawal decision. Journal of Higher Education, 57(2), 155-175.

Pike, G. R., Schroeder, C. S., \& Berry, T. R. (1997). Enhancing the educational impact of residence halls: The relationship between residential learning communities and first-college experiences and persistence. Journal of College Student Development, 38(6), 609-621.

Sax, L. J. (2000). Designing an assessment of the first college year: Results from the 1999-2000 YFCY pilot study. University of California, Los Angeles: Higher Education Research Institute Graduate School of Education \& Information Studies/Pew Charitable Trusts.

Ting, S. M. R. (1998). First-year academic success: A prediction combining cognitive and psychosocial variables for Caucasian and African American students. Journal of College Student Development, 39(6), 599-610.

Tinto, V. (1975). Dropout from higher education: A theoretical synthesis of recent research. Review of Educational Research, 45(1), 89-125.

Tinto, V. (1987). Leaving college: Rethinking the causes and cures of student attrition. Chicago: University of Chicago Press.

Tinto, V. (1997). Classrooms as communities: Exploring the educational character of student persistence. Journal of Higher Education, 68(6), 599-623.

Wilkie, C., \& Kuckuck, S. (1989). A longitudinal study of the effects of a freshman seminar. Journal of the Freshman Year Experience, 1(1), 7-16.

Woodside, B. M., Wong, E. H., \& Weist, D. J. (1999). The effect of student-faculty interaction on college students' academic achievement and self-concept. Education, 119(4), 730-733. 


\section{Significant Findings}

\section{Academic Experiences}

1. Midwestern students showed greater success "getting to know faculty" than peer students

2. Midwestern students showed greater success "adjusting to academic demands of college" than peer students

3. Midwestern students, both males and females, showed greater success "adjusting to academic demands of college" than peer male or female students

4. Female students at the midwestern and peer institutions showed a greater success "developing effective study skills" than all male students

5. Midwestern black and "other" students showed a greater success "understanding what professors expect academically" than peer black and "other" students

6. Midwestern students in all race categories showed greater success "adjusting to academic demands of college" than peer students in all race categories

\section{Out-of-Classroom Experiences}

7. Peer students showed greater satisfaction "having an overall sense of community among students" than peer students

8. Peer institutions enrolled more students "in learning cluster/learning community courses" than did Midwestern University

9. Peer institutions enrolled more female and male students "in learning cluster/learning community courses" than did Midwestern University

10. Peer students participated at a slightly higher level "in student clubs/groups" than Midwestern students

11. Midwestern "other" students as well as black and white peer students showed greater success "developing close friendships with other students" than "other" peer students and Midwestern black and white students

\section{Level of Significance}

$p<.002$

$p<.0001$

$p<.008$

$p<.024$

$p<.002$

$p<.021$

\section{Level of Significance}

$p<.0001$

$p<.0001$

$p<.0001$

$p<.0001$

$p<.0001$ 


\section{Out-of-Classroom Experiences (cont.)}

12. Peer students in all race categories showed a higher degree of satisfaction "having an overall sense of community among students" than Midwestern students in all race categories

13. More white peer students "took a first-year adjustment course" than white students at Midwestern University

14. Peer institutions enrolled more white and "other" students "in learning cluster/learning community courses" than did Midwestern University

\section{Overall Adjustment to College}

15. Female and male Midwestern students showed greater success "managing time effectively" than female and male peer students

16. Females at peer institutions and males at Midwestern University showed a greater success "developing a meaningful philosophy of life" than Midwestern females and peer males

17. White and black peer students and Midwestern "other" students showed greater success "developing a meaningful philosophy of life" than white and black Midwestern and peer "other" students

\section{Level of Significance}

$p<.003$

$p<.002$

$p<.0001$

\section{Level of Significance}

$p<.003$

$p<.0001$

$p<.0001$ 